MARTA JURCZAK-MORRIS

Instytut Badań Edukacyjnych

w Warszawie

\title{
ROSZCZENIOWOŚĆ VS UGODOWOŚĆ. POSTAWY RODZICIELSKIE W ŚRODOWISKACH SZKOLNYCH Z PERSPEKTYWY TEORII REPRODUKCJI SPOEECZNO-KULTUROWEJ PIERRE'A BOURDIEU
}

\begin{abstract}
AвSTRAct. Jurczak Marta, Roszczeniowość vs ugodowość. Postawy rodzicielskie w środowiskach szkolnych z perspektywy teorii reprodukcji społeczno-kulturowej Pierre'a Bourdieu [A Demanding Attitude vs. a Conciliatory Attitude. Parental Actions and Engagement in School Environments from the Perspective of Pierre Bourdieu's Socio-Cultural Reproduction Theory]. Studia Edukacyjne nr 45, 2017, Poznań 2017, pp. 185-209. Adam Mickiewicz University Press. ISSN 1233-6688. DOI: 10.14746/se.2017.45.13

School is a unique environment of social interactions. It generates the variety of attitudes and behaviours. This paper demonstrates differences in the attitudes towards school of parents, according to their social status. The research study emphasises that social class is one of the key determinants of ways in which parents participate in their children's education process. Likewise, it shows that educational aspirations of a certain group of parents, as well as their vision of what education should look like vary and make up specific 'class patterns' of parental participation in education. This qualitative research clarifies that most parents from advantaged social background have a clear vision on education as well as expectations towards school. They are therefore more likely to demand and complain. On the contrary, parents from a lower social class tend to be conciliatory, unquestionably trusting the school institution.
\end{abstract}

Key words: education, reproduction theory, social class, parental attitudes

\section{Wstęp}

W dobie współczesnych merytokratycznych społeczeństw, edukacja może być (i z pewnością jest) postrzegana przez wielu jako swoista szansa na sukces. W miarę wrastania w nowoczesność, jej egalitarny charakter polegający na równej i powszechnej dostępności ${ }^{1}$ rokował nadzieję na zmniej-

1 T. Szkudlarek, Edukacja i konstruowanie społecznych nierówności, [w:] Fenomen nierówności społecznych, red. J. Klebaniuk, Warszawa 2007, s. 31-52. 
szenie pogłębiających się różnic społecznych, ekonomicznych i kulturowych, będących przyczyną społecznego uwarstwienia i przynależności klasowej. Jednakże, zdaniem badaczy społecznych², nadzieje na większą demokratyzację szkolnictwa okazały się płonne, a egalitarystyczne deklaracje mają jedynie pozór powszechnego awansu rzesz nieuprzywilejowanych statusem pochodzenia. Jedną z podstawowych przyczyn takiego stanu rzeczy jest dominujący system kapitalistyczny, który z założenia "generuje nierówności" ${ }^{3}$ i tym samym przyczynia się do elitaryzacji szkolnictwa. Jednocześnie, kwestia wyrównywania szans edukacyjnych nie jawi się już jako oczywistość i może być rozumiana inaczej $\mathrm{w}$ zależności od przyjętej perspektywy ${ }^{4}$. Jedną z nich, stanowiącą źródło inspiracji do napisania tej pracy, bardzo trafnie odzwierciedlają słowa przytoczone niegdyś przez Zbigniewa Kwiecińskiego: „Szkoła nie jest walcem drogowym, by wyrównywać to, co jest zasługą jednostki i jej domu" ${ }^{5}$. To właśnie owe zasługi jednostki i jej domu stanowią szczególny przedmiot mojego zainteresowania, ponieważ wskazują potrzebę powrotu do źródła społecznych nierówności, jakim jest proces socjalizacji pierwotnej $j^{6}$. Przeniesienie środka ciężkości ze szkoły na środowisko rodzinne jako praprzyczynę nierówności społecznych - w tym także szans edukacyjnych - uważam za kluczowe (i skądinąd oczywiste), niemniej jednak wymagające wciąż dogłębnej analizy. Nie zmienia to faktu, że - jak wykazywało wielu socjologów edukacji - szkoła jest narzędziem, które podtrzymuje, a nawet pogłębia społeczne nierówności. Jednakże to właśnie rodzina, mimo coraz bardziej widocznej zmiany swej pozycji ${ }^{8}$, pozostaje wciąż czynnikiem determinującym i odgrywającym istotną rolę, "jako pierwsza podstawa społecznej selekcji jednostek do określonej pozycji społecznej" ${ }^{\prime \prime}$. Jest ona swoistą

${ }^{2}$ P. Mikiewicz, Selekcja i segmentacja społeczna jako immanentna funkcja systemu edukacji, [w:] Fenomen nierówności, s. 67-82.

${ }^{3}$ P. Długosz, Społeczne skutki zmian systemu edukacji, [w:] Zawirowania systemu edukacyjnego, red. M. Zahorska, Warszawa 2012, s. 25-46.

${ }^{4}$ Z. Kwieciński, Wolność czy równość w edukacji? [w:] Idee-Diagnozy-Nadzieje. Szkoła polska a idee równości, red. A. Męczkowska-Christians, P. Mikiewicz, Wrocław 2009, s. 19-24; J. Clark, Social justice, education and schooling: some philosophical issues, British Journal Studies, 2006, 54(3), s. 272-287.

5 Tamże, s. 20.

${ }^{6}$ P. Bourdieu, J.-C. Passeron, Reprodukcja. Elementy teorii systemu nauczania, przekł. E. Zamojska, Poznań 1992, s. 23.

7 P. Mikiewicz, Selekcja i segmentacja społeczna jako immanentna funkcja systemu edukacji, [w:] Fenomen nierówności, s. 67; M. Cylkowska-Nowak, Refleksja teoretyczna nad problemem równości analiza wybranych koncepcji, [w:] Idee-Diagnozy-Nadzieje, s. 25-50.

8 T. Szlendak, Socjologia rodziny. Ewolucja, historia, zróżnicowanie, przekł. B. Bińko, Warszawa 2010, s. 366; P. Sorokin, Ruchliwość społeczna, przekł. J. Słomczyńska, Warszawa 1968, s. 182.

${ }^{9}$ P. Sorokin, Ruchliwość społeczna, s. 180. 
„prehistorią", jak to określił Pierre Bourdieu ${ }^{10}$, na której zasadza się historia procesu edukacyjnego każdego ucznia.

W tym kontekście chciałabym przyjrzeć się funkcjonowaniu rodziców w środowisku szkolnym, by na tej podstawie stwierdzić, jaki związek istnieje między klasą pochodzenia a sposobem uczestnictwa rodziców w procesie edukacji ich dzieci. Paradygmat wyznaczający podstawy teoretyczne moich badań, to stworzona przez Pierra Bourdieu teoria reprodukcji społeczno-kulturowej.

\section{Teoria reprodukcji społeczno-kulturowej}

Koncepcja Pierra Bourdieu łączy elementy tradycji Emila Durkheima, Karola Marksa i Webera, a jednocześnie je przekracza ${ }^{11}$. To, co najbardziej charakterystyczne dla Bourdieu, to jego spiralny sposób myślenia, który - jak określił Wacquant - „rozpościera się w poprzek przestrzeni analitycznej”"12. Dzięki niemu autor Dystynkcji przezwyciężył antynomię implikowanej przez funkcjonalizm oraz teorie konfliktu strukturalnej konieczności i, podkreślanego przez Webera, działania jednostki. $W$ ten sposób dokonał rzeczy nowej. Mianowicie, użył tych dwóch pozornie sprzecznych paradygmatów w celu ukazania podwójnej natury społecznego świata ${ }^{13}$. Z jednej strony, podkreślił istnienie przymusu zewnętrznego, którym obarczone są ludzkie interakcje i wyobrażenia, z drugiej położył nacisk na ludzkie doświadczenie, które oddziałuje na kategorie percepcji i oceny (tzw. dyspozycje). Te ostatnie z kolei strukturyzują ludzkie działania i wpływają na wyobrażenia (czyli zajmowanie mentalnych stanowisk). Ponadto, Bourdieu rysuje obraz świata silnie ustrukturyzowanego, ale i dynamicznego, w którym prawa społeczne nie wyrażają tego, co Durkheim nazywa "nieuchronnymi koniecznościami”"14. Według niego, „społeczeństwo, to nie zwarta całość scalona funkcjami systemowymi, (...) krzyżującymi się konfliktami”"15. To raczej „zespół względnie autonomicznych obszarów gry [pól], niedających się podporządkować jednej logice społecznej, jakakolwiek by ona nie była"16.

W ujęciu Bourdieu, świat społeczny jawi się jako nieprzejrzysty. Struktura społeczna, którą określa mianem społecznego uniwersum, składa się

\footnotetext{
${ }^{10}$ P. Bourdieu, J.-C. Passeron, Reprodukcja, s. 101.

11 Tamże, s. 12.

${ }^{12}$ P. Bourdieu, L.J.D. Wacquant, Zaproszenie do socjologii refleksyjnej, przekł. A. Sawisz, Warszawa 2001, s. 11.

13 Tamże.

14 Tamże, s. 41.

15 Tamże, s. 20.

16 Tamże, s. 201.
} 
z wielu różnych społecznych światów o głęboko ukrytych strukturach. Owe struktury działają w dwojaki sposób - jako tak zwane obiektywności pierwszego i drugiego rzędu. Do pierwszego rodzaju należą różne postacie kapitału - w szczególności ekonomiczno-kulturowego (zasoby materialne, środki przywłaszczania dóbr i wartości). Drugi rodzaj obejmuje natomiast mentalne i cielesne schematy, które pełnią rolę symbolicznych wzorców wszelkich zachowań, uczuć, sądów, myślenia oraz praktyk, które autor Reprodukcji określił mianem habitusów. Nawiązując do Durkheima, Bourdieu zauważył również, że istnieje odpowiedniość między strukturą społeczną a strukturami myślowymi, między obiektywnymi podziałami świata społecznego (na dominujących i zdominowanych) a zasadami postrzegania i dzielenia, przypisywanymi przez ludzi tym podziałom. Zauważył nawet więcej, stwierdzając, że podziały społeczne i wzory myślowe są strukturalnie homologiczne, ponieważ te ostatnie są wynikiem przyswajania sobie przez jednostki podziałów społecznych. Inaczej rzecz ujmując, określone warunki społeczne, którym jednostka nieustannie podlega, wpajają w jej umysł kategorie percepcji i oceny (dyspozycje), charakteryzujące się trwałością, ale i modyfikowalnością zarazem. Jest to skutek procesu interioryzacji otoczenia społecznego, które wywiera na jednostce presję rzeczywistości zewnętrznej dopóty, dopóki jednostka nie zmieni tegoż otoczenia na inne. Ponadto, owe schematy klasyfikacyjne nie są naturalnie dane, lecz stanowią „stawkę walki" jednostek i grup, jaka toczy się na polu życia codziennego, polityki i reprodukcji kulturalnej ${ }^{17}$. Zatem, logika ta ostatecznie przeciwstawia się logice funkcjonalizmu, czerpiąc więcej z tradycji strukturalistycznej. Widoczne jest tu także znaczne podobieństwo do teorii strukturacji Gidden$\mathrm{sa}^{18}$, w myśl której struktura społeczna znajduje się w stanie permanentnego i dynamicznego procesu stwarzania. Dopełnienie stanowi również inspiracja, jaką autor Reprodukcji zaczerpnął od Webera stwierdzając, że "podstawowy wymiar życia społecznego stanowią walki o uznanie, a ich stawką jest nagromadzenie szczególnej formy kapitału: honoru w sensie reputacji, prestiżu"19.

Stratyfikacja społeczna w wydaniu Bourdieu wyraża się w niepodlegających wyborowi stylach życia, które funkcjonują poprzez swoje wzajemne istnienie $^{20}$. Bourdieu wyjaśnia, że hierarchia społeczna polega na „narzucaniu przez dominujących uznania ich specyficznego sposobu życia jako nadrzędnego" ${ }^{21}$, obciążając odpowiedzialnością za jej reprodukowanie w głównej

\footnotetext{
17 Tamże, s. 18.

18 A. Giddens, Constitution of Society, Berkeley 1984.

19 P. Bourdieu, J.-C. Passeron, Reprodukcja, s. 35.

${ }^{20}$ M. Gdula, P. Sadura, Style życia i porządek klasowy w Polsce, Warszawa 2012, s. 28.

21 P. Bourdieu, J.-C. Passeron, Reprodukcja, s. 64.
} 
mierze szkołę 22 . Jak istotnie podkreślają Gdula i Sadura, klasa wyższa „nie potrzebuje innych klas, aby poddawać je eksploatacji, jej nadrzędność wymaga jednak uznania i klasa niższa oraz średnia do tego uznania zostają przymuszone" 23 , czemu daje wyraz koncepcja przemocy symbolicznej.

W ujęciu Bourdieu, pionowa ruchliwość międzypokoleniowa, polegająca na ruchliwości całych kategorii społecznych względem pozycji ich rodziców, w zasadzie nie istnieje. Ruchliwość wewnątrzpokoleniowa natomiast, oznaczająca hierarchiczne przemieszczanie się jednostek poprzez podejmowane działań podnoszących swoje kwalifikacje ${ }^{24}$, jeżeli się pojawia, ma charakter sporadyczny i znacznie ograniczony. Przekonanie Bourdieu wynika, po pierwsze, z wniosków nad teorią kapitału społeczno-kulturowego, która przyznaje wyższość kapitałowi dziedziczonemu, będącemu swoistym emblematem klas dominujących względem kapitału nabytego, czyniąc ów pierwszy jedną z podstawowych przyczyn nierówności edukacyjnych. Po drugie, istotną rolę determinizmu klasowego ukazuje teoria reprodukcji kulturowej, demaskująca mechanizmy odtwarzania kultury prawomocnej przez system szkolny, który niejako w imieniu klas dominujących podtrzymuje i zatwierdza generowane przez owe klasy społeczne status quo.

Bourdieu konsekwentnie stosuje pojęcie klasy, co czyni jego koncepcję niezwykle osobliwą, ponieważ przeciwstawia się ona współczesnym tendencjom panującym $\mathrm{w}$ dziedzinie nauk społecznych, które marginalizują to zagadnienie ${ }^{25}$. Relacjonalna perspektywa wywodząca się z tradycji strukturalistycznej - od Marksa, a także i Durkheima, jest niewątpliwie punktem centralnym socjologicznej wizji francuskiego badacza ${ }^{26}$, którą w zwięzły i klarowny sposób wyłożył niegdyś jeden z wyżej wymienionych, Karol Marks: „Społeczeństwo nie składa się z jednostek, lecz z sumy więzi i relacji, w jakie są one uwikłane" 27 . Stąd, kluczowe dla epistemologii Bourdieu pojęcia: habitus i pole oznaczają sploty relacji. Odwołuje się on także do Weberowskiej wizji klas, twierdząc, że fundamentalnym wymiarem życia społecznego są walki o uznanie, których stawką jest "szczególna forma kapitału ${ }^{28 "}$, czyli reputacja i prestiż. Równocześnie, podążając wciąż za myślą Webera, a także Warnera, stwierdza, że klasy prowadzą nieustanną walkę o narzucanie sposobu widzenia świata najbardziej kompatybilnego $\mathrm{z}$ ich interesami ${ }^{29}$, polegającą na narzuceniu określonego stylu życia, który autor Dystynkcji

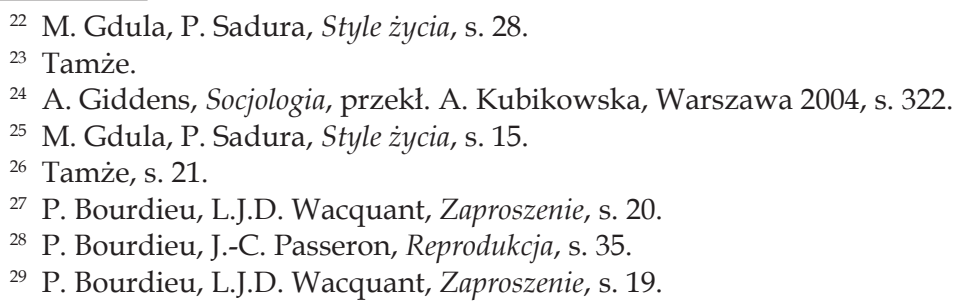


nazwał „prawomocnym" ${ }^{30}$. Swoistym novum, które Bourdieu wprowadza na grunt tych trzech sposobów myślenia o klasie, jest pojęcie habitusu jako czynnika decydującego o charakterze danego stylu życia. Ukształtowany w różnych warunkach społeczno-kulturowych habitus jest stosunkiem do świata, pewną „ucieleśnioną koniecznością" ${ }^{31}$, generującą określone praktyki oraz systemy ich klasyfikowania, czyli sądy o tych praktykach ${ }^{32}$. Zatem, jak zauważyli Gdula i Sadura, według francuskiego socjologa, style życia są określane przez habitusy i z tego też względu „dzielą ludzi klasowo w sposób fundamentalny na poziomie odruchów wobec świata i wobec siebie nawzajem" ${ }^{33}$. Owe odruchy wobec świata funkcjonują jako systemy znaków społecznych czy też "emblematów klasowych"34, świadczących o ich pospolitym bądź dystyngowanym charakterze ${ }^{35}$. I o tę klasową dystynkcję toczy się symboliczna walka.

\section{Rola środowiska rodzinnego w świetle teorii kapitału społeczno-kulturowego i reprodukcji kulturowej Pierre'a Bourdieu}

Kluczowe dla epistemologii Bourdieu pojęcia kapitału i habitusu w sposób jednoznaczny sytuują rodzinę na wyjątkowo znaczącej pozycji, czyniąc ją niejako wyznacznikiem posiadanego kapitału oraz "dawcą" habitusu pierwotnego - najbardziej trwałego i nieodwracalnego habitusu ze wszystkich możliwych. Ponadto, rodzina jest także w sposób pośredni odpowiedzialna za tworzenie określonych stylów życia generowanych przez habitus, który jest jej bezpośrednim produktem. Style życia natomiast stają się przestrzenią nieustannej walki klasowej - walki o dominację i narzucenie prawomocności. Jedną z kluczowych ról w tej walce odgrywa edukacja, będąca nośnikiem i przekazicielem szeroko rozumianej kultury, a tym samym, mówiąc językiem Bourdieu, narzędziem przemocy symbolicznej oraz władzy. W świetle teorii reprodukcji, finał tej walki jest z góry przesądzony, ponieważ szkoła, jak wiadomo, podtrzymuje kulturę klas dominujących, zwaną kulturą „,spadkobierców" ${ }^{\prime 36}$. Zatem, nie pozostaje nic innego, jak wrócić do punktu wyjścia, jakim jest rodzina, by przyjrzeć się rodzajom przekazywanych „spadków”,

${ }^{30}$ P. Bourdieu, Dystynkcja. Społeczna krytyka władzy sązenia, przekł. P. Biłos, Warszawa 2005, s. 310.

${ }^{31}$ Tamże, s. 216.

${ }^{32}$ P. Bourdieu, L.J.D. Wacquant, Zaproszenie, s. 108; P. Bourdieu, Dystynkcja, s. 216.

${ }^{33}$ M. Gdula, P. Sadura, Style życia, s. 21.

${ }^{34}$ P. Bourdieu, Dystynkcja, s. 310.

${ }_{35}$ Tamże, s. 218.

36 Tamże. 
mechanizmom ich funkcjonowania, a także ich znaczeniu w polu edukacji. W tym celu niezbędne jest rozważenie logiki świata społecznego, jako świata podwójnych obiektywności wyrażonych we wzajemnej relacji kapitału, pola i habitusu.

Autor Reprodukcji prezentuje dualistyczną wizję świata społecznego, która stanowi bez wątpienia antidotum na wszelkiego rodzaju dogmatyzację myślenia. Skonstruował bowiem wizję społecznego uniwersum, prowadzącego tak zwany "podwójny żywot" ${ }^{\prime 37}$. Mając świadomość, jak istotne jest dokonywanie statystycznych analiz zjawisk należących do świata społecznego, które de facto stanowią źródło wiedzy o nim, zdawał sobie również sprawę, że analizy te nie mogą być pozbawione aspektu subiektywistycznego. Ukazuje on zatem, że całe spektrum zjawisk i rzeczy składających się na społeczne uniwersum nie jest postrzegane jednakowo przez wszystkich aktorów społecznych, ale że ma różne znaczenie dla poszczególnych ich grup (klas). Te ostatnie, to według niego nic innego, jak grupy podmiotów działających, połączone podobnymi warunkami egzystencji wyrażanymi przez formy posiadanego kapitału. Członkowie poszczególnych klas mają wytworzone w umyśle podobne schematy myślowe i oceniające, zwane habitusami, dzięki którym postrzegają rzeczywistość w podobny sposób i zgodnie z tym sposobem podejmują praktyki oraz działania dnia codziennego, składające się na określone style życia. W ten sposób Bourdieu ukazuje podwójny mechanizm społecznego funkcjonowania grup aktorów społecznych, który ma wymiar klasowy. Są to praktyki i działania uwarunkowane posiadaniem różnego rodzaju kapitału (ekonomicznego, kulturowego i społecznego) oraz zasady podejmowania i oceniania tych praktyk, uwarunkowane $\mathrm{z}$ kolei habitusem. Zauważmy jednak, że za tym podwójnym mechanizmem funkcjonowania społecznego stoi rodzina, jako twórca czy też inicjator zarówno praktyk i działań podejmowanych przez aktorów społecznych, jak i zasad strukturujących i oceniających te działania. Kluczowe zatem dla zrozumienia procesów reprodukcji staje się poznanie sposobów działania rodziców w polu edukacji. Czy i w jaki sposób widoczna jest różnica społecznego ulokowania rodzin w sposobie odnajdywania się w polu szkolnym? Pytanie to stanowi podstawę badania empirycznego, którego wyniki przedstawię w dalszej części pracy.

Przedmiotem prowadzonych przeze mnie badań jest pole edukacji. Moim głównym zadaniem jest analiza postaw rodzicielskich jako potencjalnego źródła dystrybucji kapitału, potrzebnego do odniesienia zwycięstwa w polu osiągnięć edukacyjnych uczniów. Bezpośredniej obserwacji poddano sposoby uczestnictwa rodziców uczniów klas 1 - 3 szkoły podstawowej w procesie edukacji.

${ }^{37}$ P. Bourdieu, L.J.D. Wacquant, Zaproszenie, s. 12. 


\section{Cele badań}

Moim głównym dążeniem jest opisanie postaw rodziców w kontaktach ze szkołą, a także charakteru nawiązywanych przez nich relacji. Warto jednak podkreślić, że cel ten służy nie tylko opisaniu, lecz przede wszystkim zrozumieniu zjawisk i zachowań, pojawiających się w dwóch badanych przez mnie środowiskach szkolnych. Ponadto, pociąga on za sobą również konieczność wyjaśnienia potencjalnych różnic w nawiązywanych przez rodziców kontaktach ze szkołą, nabierając tym samym charakteru wyjaśniającego ${ }^{38}$, który pozwoliłby na udzielenie odpowiedzi o przyczyny zaistniałego stanu rzeczy. Mamy tu jednak do czynienia z przypadkiem dość osobliwym, ponieważ Pierre Bourdieu poprzez swoją koncepcję kapitału społeczno-kulturowego udzielił już niejako na to pytanie odpowiedzi, wskazując jasno na różnice klasowe uwarunkowane różnicami kapitału. Powstaje więc dedukcyjna „klamra metodologiczna", w wyniku której mogę przetestować hipotezę Bourdieu o dystynkcji klas wyższych, przenosząc ją na grunt szkolny, a konkretnie na zaangażowanie rodziców w edukację ich dzieci oraz na ich współpracę ze szkołą. Zatem, ów cel wyjaśniający służy przede wszystkim empirycznej weryfikacji zaczerpniętych od Bourdieu teoretycznych założen, na podstawie których można wnioskować, że zaangażowanie rodziców z klas wyższych we współpracę ze szkołą ma inny charakter niż sposób, w jaki rodzice z klasy niższej wchodzą $\mathrm{w}$ relacje ze środowiskiem szkolnym.

Problemy badawcze dotyczące partycypacji rodziców w procesie edukacji swoich podopiecznych skupiają się wokół kluczowego słowa, jakim jest "różnica”. Jak powiedział niegdyś Bourdieu, tożsamość klasowa afirmuje się w różnicy ${ }^{39}$, dlatego w sposób szczególny koncentruję na niej badawczą uwagę. Podstawowe pytanie, jakie nasuwa się w kwestii funkcjonowania obu grup rodziców brzmi: po pierwsze, jakie postawy przyjmują rodzice uczniów pochodzących z różnych środowisk szkolnych? Po drugie, czy istnieją pomiędzy nimi różnice pozwalające na określenie sposobu, w jaki przynależność do klasy społecznej kształtuje charakter rodzicielskich relacji nawiązywanych ze szkołą?

\section{Dobór próby, jednostki analizy i wymiar czasowy}

Mając świadomość celu moich badań, próbę dobrałam w sposób arbitralny i nieprobabilistyczny. Dlatego, wyselekcjonowałam dwie wrocławskie szkoły o możliwie największej rozbieżności statusowej. Z jednej strony, szko-

${ }^{38}$ E. Babbie, Badania społeczne w praktyce, przekł. A. Betlejewska, Warszawa 2003, s. 109.

39 Por. P. Bourdieu, Dystynkcja. 
łę muzyczną o stosunkowo wysokim prestiżu (nazwaną symbolicznie szkołą X), zakładając, że uczęszczają do niej dzieci o wyższych zasobach kapitału ekonomiczno-kulturowego; z drugiej, regularną szkołę podstawową (określoną analogicznie mianem szkoły Y), na temat której miałam dodatkowe informacje sugerujące, iż znaczna część jej uczniów wywodzi się ze środowisk o niższym statusie społecznym. Badania miały charakter dynamiczny i symultaniczny zarazem, ponieważ przeprowadzałam je w kilkumiesięcznym przedziale czasowym (od stycznia do maja) w dwóch szkołach równocześnie.

Wybrana przeze mnie strategia empiryczna miała charakter etnograficzny, gdyż wymagała „uczestniczenia (...), obserwowania biegu zdarzeń, słuchania rozmów, zadawania pytań - jednym słowem, wymagała wszystkich dostępnych danych, które rzucają nieco światła na kwestie będące przedmiotem badań" ${ }^{40}$. Dlatego, posłużyłam się technikami jakościowymi, do których należą: wywiad kwestionariuszowy, wywiad swobodny oraz obserwacja nieuczestnicząca jawna.

\section{Pole szkolne \\ - szkolne priorytety $\mathrm{w}$ treściach adresowanych do rodziców}

Z całą pewnością, na uwagę zasługuje przekaz treści skierowanych w stronę rodziców, zawartych w różnego rodzaju ogłoszeniach widniejących na szkolnych korytarzach. Odsłania on bowiem pewne charakterystyczne dla określonej kultury szkolnej tendencje i priorytety, dostosowane do potencjalnych odbiorców tego przekazu, w tym wypadku rodziców. Treści te dostarczają zatem informacji nie tylko o specyficznym programie danej szkoły, ale również o samych rodzicach.

W szkole $\mathrm{X}$ większość ogłoszeń dotyczyła oferty edukacyjnej, dzięki której uczeń będzie mógł uzyskać potrzebną oraz dostosowaną do jego potrzeb pomoc. Do oferty tej należały ogłoszenia o zajęciach psychoedukacyjnych dla rodziców, by poznali sposoby skutecznego wspierania rozwoju swoich dzieci, a także informacje oraz kontakt z poradnią logopedyczną. Kolejnym tematem jednej z gazetek adresowanych do rodziców było „Osiem rad dla rodziców nadpobudliwych dzieci”. Ponadto, można było również zauważyć informacje na temat czytania, jako kluczowej umiejętności wspomagającej rozwój, która jednocześnie stanowi zachętę do zaangażowania się w projekt pod hasłem „Cała Polska czyta dzieciom”. Dodatkowo, jako interesujące zjawisko, jawi się gazetka z Deklaracją Praw Dziecka, która nie wydaje się do końca kompatybilna z etosem tradycyjnej „surowej” szkoły, w jaki wpisywała się

${ }^{40}$ M. Hammersley, A. Atkinson, Metody badań terenowych, Poznań 2000, s. 11; P. Mikiewicz, Społeczne światy szkót średnich. Od trajektorii marginesu do trajektorii elit, Wrocław 2005, s. 131. 
szkoła X. Niemniej jednak widać wyraźnie, że kluczowym aspektem ukrytym w treściach ogłoszeń kierowanych do rodziców jest nic innego, jak rozwój intelektualny $\mathrm{w}$ szerokim tego słowa znaczeniu. Począwszy od umiejętności czytania, jako "prapoczątku” sukcesu na edukacyjnej ścieżce, poprzez właściwy rozwój mowy oraz umiejętne stymulowanie procesu edukacyjnego uczniów w ramach kursu psychoedukacyjnego oferowanego rodzicom, skonczywszy na poradach dotyczących dzieci "trudnych". Ponadto, swoistym przywilejem rodziców X w zakresie kultury szkolnej jest posiadanie przez nich własnej tablicy informacyjnej, na której mogą zamieszczać różnego rodzaju ogłoszenia, w większości dotyczące oferty sprzedaży instrumentów muzycznych. Na uwagę, z całą pewnością, zasługuje również działalność rady rodzicielskiej, która także zaznacza swą obecność w szkole i włącza się w sferę życia szkolnego z własną skrzynką korespondencyjną, umieszczoną tuż przy tablicy ogłoszeniowej rodziców. Widać zatem wyraźnie, w jak znacznym stopniu rodzice wpisują się w kulturę szkolną, podejmując w jej polu własne inicjatywy i działania.

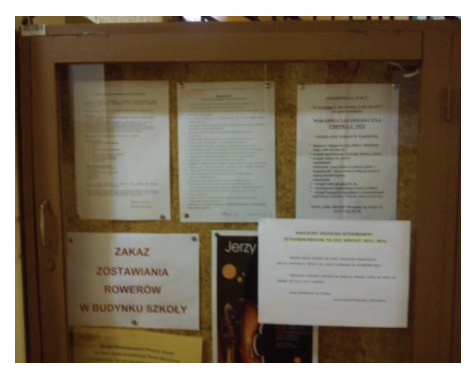

Gablota informacyjna w szkole X
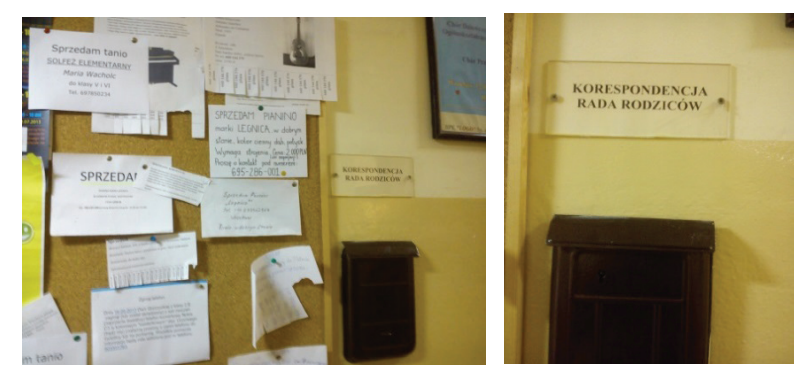

Tablica ogłoszeniowa rodziców w szkole X

W przypadku szkoły Y dostrzegalna jest inna logika przekazywanych treści. Przede wszystkim, widoczny jest nacisk na rozwój ruchowy uczniów poprzez promowanie aktywnego spędzania czasu wolnego. Dlatego, główne komunikaty w kierunku rodziców dotyczyły oferty wyjazdów na kolonie i obozy z dofinansowaniem (aspekt finansowy pozostaje $\mathrm{w}$ ścisłym związku z kulturą szkoły), jak również kursów nauki pływania oraz gry w szachy. Interesująco, poza ogłoszeniem o możliwości skorzystania z poradni logopedycznej, nie znalazłam żadnych innych informacji skierowanych do rodziców, związanych z doskonaleniem rozwoju intelektualnego uczniów. Ponadto, obok ogłoszeń odnośnie zorganizowanych wyjazdów letnich, w sekcji zatytułowanej "Informacje dla rodziców” widniał znacznej wielkości plakat rozpowszechniający "SKO BP”, czyli Szkolną Kasę Oszczędności. Jego główny postulat brzmiał: „Ucz dziecko oszczędzania od najmłodszych lat”, który nie wymaga obszernego komentarza. 

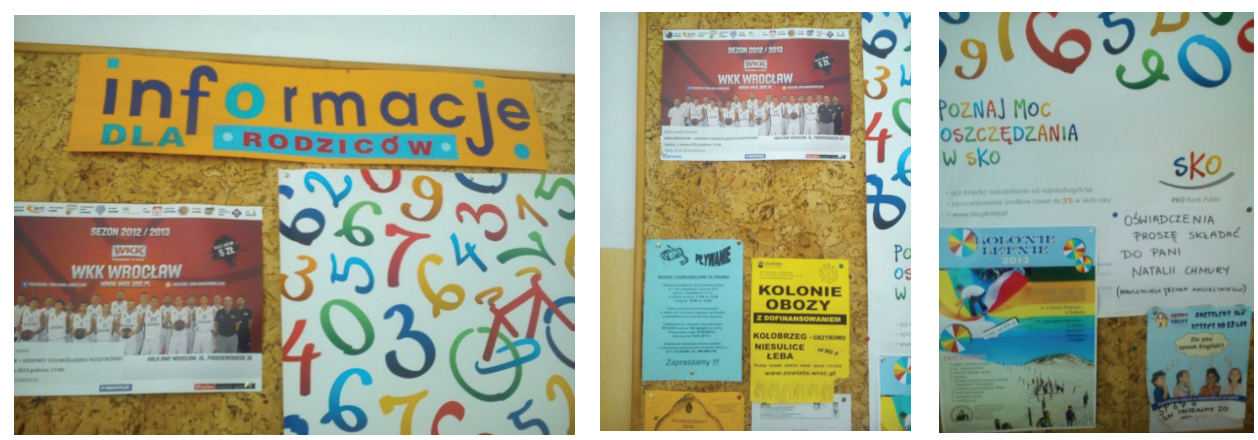

Gablota informacyjna w szkole Y

Różnica w przekazywanych przez obydwie szkoły treściach jest znacząca i zasadniczo odzwierciedla dwa różne rodzaje szkolnych priorytetów, będących integralną częścią kultury szkół, a także do pewnego stopnia ukazuje zasoby bądź deficyty poszczególnych form kapitałów obu grup rodziców. Kultura elitarnej szkoły $X$ za podstawowy cel stawia sobie (obok rozwoju muzycznego) rozwój intelektualny uczniów, odwołując się do kapitału kulturowego rodziców oraz jednocześnie gwarantuje rodzicom szerokie pole do ich własnych działań, czego wyrazem jest symboliczna skrzynka korespondencyjna rady rodziców. Natomiast szkoła Y wyraźnie akcentuje rozwój aktywności ruchowej swoich wychowanków i uwzględniając deficyty kapitału ekonomicznego rodziców, oferuje rozwiązania dostosowane do ich możliwości, aby ów rozwój ruchowy młodzieży wspomagać. Poza tym, nie dostrzegłam żadnych dodatkowych form zaangażowania rodziców w życie szkoły, jak też żadnej zagwarantowanej przez szkołę możliwości ku temu.

\section{Charakterystyka statusu społecznego rodziców w szkołach X i Y}

Zarówno pod względem statusu wykształcenia, jak i statusu zawodowego badanie kwestionariuszowe wykazało, że mamy do czynienia ze środowiskiem bardziej homogenicznym w przypadku rodziców uczniów ze szkoły muzycznej $(X)$ niż w przypadku rodziców uczniów z regularnej szkoły podstawowej (Y). Zdecydowana większość rodziców szkoły X zadeklarowała bowiem, że ma wykształcenie wyższe, natomiast w przypadku rodziców szkoły Y deklarację taką złożyła niespełna połowa rodziców. Podobnie rzecz się ma ze statusem zawodowym, którego przewaga leży zdecydowanie po stronie rodziców szkoły $\mathrm{X}$ o relatywnie wyższym prestiżu zawodowym, aniżeli rodziców szkoły Y. Na podstawie tegoż kryterium statusowego, mierzonego stopniem wykształcenia oraz profesji zawodowej (obie zmienne są ze sobą 
silnie skorelowane), można przyjąć, że dzieci ze szkoły muzycznej reprezentują klasę relatywnie wyższą względem uczniów zwykłej szkoły podstawowej (pamiętając, iż klasa szkoły Y stanowi mimo wszystko grupę statusowo niehomogeniczną).

\section{Rodzicielska wizja edukacji oraz aspiracje edukacyjne}

Rozważając kwestię oceny wartości oraz roli edukacji, wywiad kwestionariuszowy potwierdził wyniki badań Annette Lareau ${ }^{41}$ i ukazał nową, zaskakującą perspektywę. Mianowicie, rodzice ze zwykłej szkoły podstawowej uznali rolę edukacji nie tylko za bardzo istotną, jak w większości uczynili rodzice ze szkoły muzycznej, lecz zdecydowana większość oceniła edukację jako czynnik kluczowy dla dalszego rozwoju swoich dzieci. W efekcie, rodzice ze szkoły Y przyznali edukacji wyższą wartość niż rodzice z prestiżowej szkoły X. Ponadto, jako swego rodzaju przypieczętowanie tego wyniku, jeden rodzic szkoły $X$ ocenił edukację tylko jako „istotną", czego nie uczynił żaden rodzic ze szkoły $Y$, dla których edukacja ich dzieci miała znaczenie „kluczowe”. Wyniki te jawią się zatem jako zaskakujące i niejako sprzeczne z logiką. Powstaje pytanie o przyczynę takiego stanu rzeczy. Dlaczego rodzice uczniów ze zwykłej, nie wyróżniającej się szkoły podstawowej cenią edukację bardziej niż niektórzy rodzice uczniów ze szkoły elitarnej, do której uczęszczają wyselekcjonowane jednostki? Wnioski płynące z badań Annette Lareau sprawiają, że nie ma nic zadziwiającego w tym, iż rodzice ze szkoły Y podkreślają znaczenie edukacji. Czynią to podobnie jak rodzice o wyższym statusie społecznym, jednak ich deficyty kapitałowe nie pozwalają im podejmować określonych działań w tym kierunku. Innymi słowy, rodzice ci pozostają wyłącznie na poziomie deklaratywnym w kwestii wartościowania edukacji. Zadziwienie i swego rodzaju fenomen wynika natomiast $\mathrm{z}$ faktu, że rodzice o stosunkowo wyższym statusie społeczno-ekonomicznym ocenili wartość edukacji niżej niż rodzice o niższych zasobach kapitałowych. Mamy więc do czynienia $\mathrm{z}$ Mertonowskim schematem niespodzianki ${ }^{42}, \mathrm{w}$ wyniku którego ,jakiś nieoczekiwany (...) fakt, przyczynia się do rozwinięcia nowej teorii albo rozszerzenia już istniejącej"43. Myślę, że wyjaśnienia tego stanu rzeczy należy szukać w specyfice szkoły muzycznej. Otóż szkoła ta, będąca

${ }^{41}$ Annette Lareau - amerykańska badaczka z University of Pennsylvania, która w swoich pracach, tj. Social Class Differences in Family-School Relationships: The Importance of Cultural Capital, Sociology of Education, 1987 (April), 60, Southern Illinois University, stworzyła teoretyczną siatkę stylów rodzicielskich, opartych na zasobach kapitału kulturowego i ekonomicznego.

${ }^{42}$ K.R. Merton, Teoria socjologiczna i struktura społeczna, przekł. E. Morawska, J. WertensteinŻuławski, Warszawa 1982, s. 170.

${ }^{43}$ Tamże, s. 170-171. 
z założenia swoistym „,bastionem kultury”, stwarza uczniom wiele różnorodnych możliwości dalszego rozwoju, a w ich rodzicach kształtuje różne, nie zawsze konwencjonalne, sposoby myślenia na temat dalszej ścieżki zawodowej swoich dzieci. W rezultacie, rodzice ci niekoniecznie utożsamiają przyszłość swoich podopiecznych $\mathrm{z}$ ich rozwojem intelektualnym $\mathrm{w}$ ścisłym tego słowa znaczeniu. Na podstawie przeprowadzonych wywiadów wyodrębniłam dwie tendencje charakterystyczne dla rodziców szkoły X, które mogą stanowić wyjaśnienie powodu, dla którego część rodziców z prestiżowej szkoły muzycznej uznała, że edukacja w życiu ich dzieci nie pełni roli najistotniejszej. Pierwszą z nich jest odejście od tak zwanej szkoły tradycyjnej w kierunku bardziej nowatorskich rozwiązań, dzięki którym dzieci mogłyby przede wszystkim nauczyć się kreatywności i twórczego myślenia, a także zdobyć wiedzę o sobie, by w przyszłości robić to, co lubią i co czyni je szczęśliwymi. Oto wypowiedź jednej z matek uczniów ze szkoły muzycznej: Jestem rozczarowana tym rokiem w szkole $X$. Generalnie jestem rozczarowana tradycyjna szkoła (...) Nie zależy mi na tym, żeby moje dziecko było 'naj'. Chcę, żeby rozwijało się w kierunku, który lubi, zgodnie ze swoimi możliwościami i zainteresowaniami. Zależy mi na nauczeniu go samodzielnego myślenia i kreatywności.

Widać wyraźnie nastawienie na rozwój dziecka jako samodzielnego podmiotu, rozwijającego swoje pasje, które de facto będą wyznaczać jego dalszą drogę życiową. Charakterystyczny brak elementu rywalizacji i brak dążenia do uczynienia z dziecka przysłowiowego "omnibusa" stanowią niewątpliwie dystynktywną cechę tej grupy rodziców o wysokim statusie społecznym. Rozczarowanie kończącym się pierwszym rokiem edukacji w szkole $X$ wynikało zarówno z formy, jak i jakości kształcenia uczniów. W kontekście formy kształcenia można było zauważyć $\mathrm{w}$ dalszej wypowiedzi respondentki krytykę i negację wszelkich przejawów apodyktyczności, z którymi jej córka zetknęła się w szkole, ponieważ - jak stwierdziła matka: idealny nauczyciel to mentor, który inspiruje, a nie ten, który jest apodyktyczny i narzuca swoje zdanie innym. Widać zatem obecny w myśleniu tej grupy rodziców konstruktywistyczny dyskurs tak zwanej nowej pedagogiki, sytuującej w centrum procesu edukacyjnego dziecko i uwzględniającej jego perspektywę ${ }^{44}$. Jako znamienny jawi się również fakt, iż rodzice ci traktują edukację bardziej w kategoriach procesu aniżeli mierzalnego efektu, stąd wyczuwalny dystans wobec wszelkich form rywalizacji. W swej wypowiedzi respondentka konsekwentnie ukazywała bezużyteczność tradycyjnej edukacji z jej apodyktycznymi metodami, twierdząc, iż nie znalazły one żadnego pozytywnego odzwierciedlenia w jakości kształcenia. Z sentymentem wypowiadała się zaś na temat wcześniej-

${ }^{44} \mathrm{H}$. Roberts, Listening to Children: and Hearing Them, [w]: Research with Children, red. P. Christensen, A. James, New York 2000, s. 260-275. 
szych doświadczeń swojej córki nabytych w jednym z autorskich przedszkoli, kwitując wymownie: gdy moja córka była w autorskim przedszkolu, odpowiadata catymi zdaniami, a teraz odpowiada "nie wiem".

Wobec takiego stanu rzeczy wyłoniła się jeszcze jedna, charakterystyczna dla tej grupy rodziców cecha, jaką jest kreatywność. Rodzice ci nie pozostają na stanowisku bezradnych krytyków, lecz przeciwnie - jawią się jako aktywne podmioty działające, gotowe podejmować własne inicjatywy. Dowodem na to jest wypowiedź, w której jeden z rodziców stwierdził jasno i z pełnym przekonaniem, że chce stworzyć autorską szkołę na wzór jednej z poznańskich podstawówek. Nie sposób nie dostrzec determinacji tej grupy rodziców w celu zapewnienia swoim dzieciom właściwej edukacji. Niemniej jednak, pojęcie to utożsamiane jest przez nich nie tyle z wysokim IQ i świetnymi wynikami szkolnymi, które ich dzieci miałyby osiągać (choć naiwne byłoby założenie, że ten aspekt pozostaje bez znaczenia), lecz przede wszystkim z wysoką samoświadomością, poznaniem swoich mocnych stron, które umożliwiłyby im podążanie za pasją i realizowanie się w dalszym życiu. Używając terminologii badawczej, jest to podejście zdecydowanie jakościowe, kładące nacisk na rozwijanie konkretnych zainteresowań, bez silenia się na bycie najlepszym we wszystkich dziedzinach.

Druga tendencja typowa dla innej grupy rodziców (skądinąd łatwa do zidentyfikowania) przejawia się z kolei w przyznawaniu kluczowej wartości rozwojowi muzycznemu swoich dzieci, a nie edukacji jako takiej. Rodzice ci w żadnym wypadku nie deprecjonują wartości edukacji, lecz przenoszą środek ciężkości z rozwoju intelektualnego w stronę rozwoju muzycznego, czyli innymi słowy - umiejętności praktycznych. Ojciec jednej z uczennic o słabych osiągnięciach edukacyjnych na tle klasy powiedział otwarcie, że: jego plany względem córki związane sa z muzyka, ponieważ bardzo dobrze jej idzie, i starszej [córce] też oraz że córka wygrata kilka ogólnopolskich konkursów. Ten sam rodzic postrzega interesująco edukację jako proces, który powinien dokonywać się wyłącznie w szkole, co de facto stoi w opozycji z powszechną tendencją myślenia o edukacji, charakteryzującą klasę wyższą. Jednak zasadnicze pytanie, jakie mi tenże rodzic zadał, negując jednocześnie pretensjonalnym tonem głosu jego treść, nie pozostawia co do tego cienia wątpliwości: To dziecko ma szkołe $w$ szkole czy $w$ domu? $W$ domu szkoła i w szkole szkoła? Jest to zjawisko nie lada zaskakujące dla tej grupy rodziców, którzy w większości, jako klasa wyższa o większych zasobach kapitałowych, angażują się w edukację swoich dzieci, włączając $w$ nią niejako $\mathrm{w}$ sposób naturalny środowisko domowe. Widać zatem znaczne rozbieżności pomiędzy rodzicami uczniów szkoły $X$, którzy nie są jednomyślni co do sposobu, w jaki postrzegają edukację. Ponadto, jeżeli chodzi o pole osiągnięć muzycznych, nie sposób pominąć przy toczonej przeze mnie w poprzednim podrozdziale wypowiedzi ucznia, jasno wskazującej 
na przerost ambicji rodzica, który oczekiwał od dziecka perfekcyjnej gry do tego stopnia, iż chłopiec stwierdził, że granie "rujnuje mu życie”, ponieważ matka krzyczy na niego, gdy popełnia błąd w trakcie gry na instrumencie. W konsekwencji, doprowadziło to chłopca do konkluzji, że nie jest przez matkę kochany. Mamy więc do czynienia z całym spektrum rozmaitych postaw rodzicielskich, które nie są homogeniczne, lecz dostarczają wieloaspektowego wglądu w sposoby myślenia rodziców o edukacji oraz ich dążenia względem własnych dzieci.

Niezwykle ciekawie i równie specyficznie przedstawia się z kolei sposób definiowania idealnej szkoły przez rodziców szkoły Y. Chociaż cenią edukację bardzo wysoko, w odróżnieniu od rodziców szkoły $X$ (nurtu kontestującego tradycyjną szkołę), nie mają wygórowanych wymagań i de facto nie zastanawiają się nad jej istotą, czyli nad tym jaka szkoła byłaby najlepsza dla ich dzieci. Dla przykładu przytaczam wypowiedź jednej mamy: Nie zastanawiałam się nigdy nad tym, czego mu [synowi] brakuje. Ta szkoła zapewnia mu wszystko. W rozmowie odnosiło się wrażenie, że definiowanie szkoły w kategoriach tradycyjności bądź nowatorskości jest zupełnie dalekie od sposobu, w jaki rodzice szkoły Y o niej myślą. Z ich perspektywy, rzeczywistość szkolna i sama koncepcja szkoły jawiła się bardziej jako prosta zależność wyrażona przez rodzica jednej z uczennic: Dopóki się dziecko uczy, szkoła jest fajna. Uderzający jest fakt, iż nie ma w tych słowach cienia roszczeniowości, własnych wymagań i oczekiwań pod względem programu czy używanych przez nauczyciela metod poza jednym, żeby dziecko "chciało" się uczyć. Widać tu zatem swoiste odwrócenie porządku, w postaci akceptowania każdej formy nauczania, dopóki jest skuteczna w motywowaniu ucznia. Rodzic w swej wypowiedzi posunął się dalej, stwierdzając: Dziecko może uczyć się wszędzie, nawet w najgorszej szkole. Wcale nie jest powiedziane, że w szkole prywatnej, za która muszę wytożyć kolosalne pieniądze, dziecko będzie się uczyło lepiej. Ta pewnego rodzaju racjonalizacja, wynikająca w dużej mierze z sytuacji finansowej, w jakiej znajduje się większość rodziców szkoły Y (wnioskując po wykonywanych przez nich zawodach) świetnie ilustruje działanie habitusu jako ucieleśnionej konieczności. Bowiem niższe zasoby kapitału ekonomicznego tej grupy rodziców przekładają się jednocześnie na ich kapitał kulturowy, którego odpowiednikiem jest klasowy habitus $\mathrm{w}$ postaci określonego myślenia na temat edukacji. W konsekwencji, myślenie to różni się znacznie od punktu widzenia rodziców szkoły $X$, którzy ze względu na wykonywanie bardziej prestiżowych profesji, nie są ograniczeni kapitałem ekonomicznym, lecz przeciwnie - ów kapitał niejako wzmacnia ich kapitał kulturowy, tworząc "duet” mający swój odpowiednik w ich klasowym habitusie, który każe im myśleć o edukacji w określony - inny od powziętego przez rodziców szkoły Y - sposób. 


\section{Zaangażowanie rodziców $\mathrm{w}$ edukację dzieci}

\section{Środowisko domowe}

Obydwie grupy rodziców przywiązują równie istotną wagę do rozmowy z dziećmi na temat szkoły, gdyż - generalnie rzecz ujmując - zarówno rodzice szkoły $X$, jak i rodzice szkoły $Y$ oceniają edukację relatywnie wysoko. W związku z tym rozmawiają o niej ze swoimi dziećmi często, a nawet bardzo często. Tylko jedna osoba z grupy rodziców szkoły Y oraz dwie z grupy rodziców szkoły X czynią to czasami. Niemniej jednak, formy zaangażowania wymagające więcej czasu i konkretnego działania, takie jak pomoc w odrabianiu lekcji, obecność w szkole oraz frekwencja na wywiadówkach, przedstawiają się już nieco inaczej i uwidaczniają specyfikę wykonywanych przez rodziców zawodów, szczególnie w zakresie elastyczności czasowej. W dalszej perspektywie świadczą one niejednokrotnie o ich ekonomiczno-kulturowych zasobach kapitałowych. Otóż, rodzice o wyższym statusie społecznym deklarują w większości, że pomagają swoim dzieciom w odrabianiu lekcji bardzo często, nieliczni zaś udzielają tej pomocy tylko często. Natomiast, rodzice o niższych zasobach kapitałowych, mimo że większość z nich także pomaga swoim podopiecznym wypełniać szkolne obowiązki, odpowiadali również, że nie robią tego wcale lub tylko czasem, toteż widać pojawiającą się w tym względzie różnicę.

\section{Środowisko szkolne}

Jeżeli chodzi o frekwencję na wywiadówkach, to jest ona dość wymowna i ukazuje, że różnice między rodzicami szkoły X i Y pogłębiają się już znacznie. $W$ szkole $X$, zarówno wskutek relacji nauczycielki, jak i z własnych obserwacji, mogę stwierdzić, że na wywiadówce pojawiło się dwadzieścia jeden na dwudziestu czterech rodziców, co stanowi relatywnie wysoką frekwencję. W przypadku rodziców szkoły $Y$, obecność ta była zdecydowanie słabsza i wynosiła zaledwie czternastu na dwudziestu czterech opiekunów. Dodatkową wiedzę na temat funkcjonowania rodziców szkoły $\mathrm{Y}$ w tym względzie stanowi wypowiedź nauczycielki, która stwierdziła, że wszyscy rodzice przychodzą tylko na początkową i semestralną wywiadówkę, natomiast ich ogólne zaangażowanie w życie klasy jest słabe. Widać zatem brak tendencji do permanentnego uczestniczenia i zaangażowania w edukację swoich dzieci oraz przesunięcie w kierunku bardziej doraźnej partycypacji wówczas, kiedy rzeczywiście "trzeba być" na wywiadówce. Sytuacja ta nabiera jeszcze wyraźniejszego kolorytu, gdy zestawimy z nią dane o monitorowaniu postępów edukacyjnych uczniów szkoły $Y$, dokumentowanych przez nauczyciela w tak zwanym e-dzienniku. Według relacji nauczycielki, jedynie dwóch rodziców szkoły Y (na dwudziestu czterech) loguje się systematycznie do tegoż dzienni- 
ka i sprawdza wyniki edukacyjne swoich dzieci. Rodzice szkoły X natomiast, jak wiadomo z relacji nauczycielki, pozostają w stałym kontakcie mailowym z wychowawcą i tym sposobem nieustannie monitorują swoje dzieci, chociaż ze względu na niższy stopień komputeryzacji szkoły $X$, nie mają równie łatwego wglądu w ich edukację, ponieważ szkoła nie prowadzi e-dzienników. Jednakże, jak widać na podstawie wyników badań, nie stanowi to dla nich poważnej przeszkody.

\section{Postawy w trakcie wywiadówki}

Niezwykle istotnym aspektem zaangażowania rodziców w edukację własnych dzieci jest sposób, w jaki uczestniczą oni w wywiadówkach. Zasadniczą różnicę pomiędzy rodzicami szkoły X i Y można było dostrzec już w pierwszych kilku minutach uczestnictwa w spotkaniu.

Po pierwsze, rodzice szkoły $X$ stanowili grupę niebywale skoncentrowaną na przebiegu wywiadówki, a ich jednomyślność w sposobie zachowania stanowiła czynnik integrujący. Nie można było wśród nich usłyszeć jakichkolwiek rozmów lub zajmowania się czymś innym niż przekazywane przez nauczyciela treści. Sprzyjało temu z pewnością specyficzne rozmieszczenie stołów na kształt prostokąta, w wyniku którego rodzice wraz z nauczycielem siedzieli naprzeciw siebie i utrzymywali ze sobą stały kontakt wzrokowy. W przypadku rodziców szkoły $Y$, rzecz się ma inaczej. W klasie można było usłyszeć charakterystyczny „dwugłos”, spowodowany rozmowami pomiędzy poszczególnymi grupami znających się rodziców oraz monologiem nauczyciela. W związku z tym, ich uwaga poświęcona przekazywanym treściom nie była tak intensywna, jak w przypadku rodziców szkoły $X$, czego dowodzi fakt, że niektórzy wysyłali podczas spotkania telefoniczne wiadomości tekstowe, co w szkole muzycznej nie miało w ogóle miejsca i bardzo prawdopodobne, że zostałoby poczytane za zachowanie niestosowne. Ustawienie ławek w klasie w szkole $Y$ także nie sprzyjało integracji, jako że każdy rodzic, niczym "samotna wyspa", siedział przy stoliku odwrócony plecami do większości osób, skierowany twarzą wyłącznie w stronę nauczycielki.

Po drugie, innym ciekawym wskaźnikiem zaangażowania rodziców szkoły $\mathrm{Y}$ w edukację ich dzieci była liczba osób notujących sugestie nauczyciela dotyczące diagnostycznego sprawdzianu przewidzianego na koniec drugiej klasy. Otóż, przypuszczenia nauczycielki odnośnie potencjalnego materiału, jaki może się pojawić na sprawdzianie, notowało siedmioro z czternastu obecnych rodziców, czyli zaledwie połowa, a niespełna jedna trzecia wszystkich rodziców (jako że klasa liczy dwadzieścia cztery osoby). Co prawda, nie miałam możliwości zestawienia tych danych z postawą rodziców szkoły $\mathrm{X}$, ponieważ ich dzieci, będąc o rok młodsze, nie podlegały jeszcze w żaden sposób ocenie, mimo wszystko stanowią one istotną informację na temat samych 
rodziców szkoły $\mathrm{Y}$ oraz stosunkowo niskiego stopnia ich zaangażowania $\mathrm{w}$ tym względzie. Niemniej jednak, niektórzy rodzice z grupy zainteresowanych sprawdzianem, wykazali gorliwość, upewniając się przy okazji ustalania szczegółów na temat wycieczki klasowej, czy jej termin nie będzie kolidował z terminem sprawdzianu. Widać zatem dbałość tej części rodziców grupy szkoły Y o edukację dzieci i hierarchiczne usytuowanie jej ponad wszelkimi innymi aktywnościami szkolnymi. Mamy więc do czynienia z brakiem homologii wśród rodziców szkoły Y.

Inną formę zaangażowania stanowi gotowość aktywnego uczestnictwa w życiu klasy w postaci reakcji zwrotnych wobec zasygnalizowanych przez nauczycielkę klasowych potrzeb. Różnicę pomiędzy rodzicami szkoły X i Y $w$ tym względzie obrazujenajtrafniej analogiczna sytuacja zaistniała w obydwu klasach. W szkole muzycznej, podczas ustalania formy przedstawienia, które uczniowie mieli zaprezentować pod koniec roku całej szkole, nauczycielka zapytała, który rodzic podjąłby się zrobienia kukiełek. Odpowiedź na tę prośbę okazała się ze strony rodziców szkoły $X$ natychmiastowa. W klasie szkoły Y natomiast, na zgłoszenie do upieczenia jednego ciasta na festyn, nauczycielka czekała co najmniej dwie minuty wypełnione głuchą ciszą, przerywaną raz po raz wznawianą przez nią prośbą. Niewątpliwie, jedną z odpowiedzi na pytanie o przyczyny takiego stanu rzeczy, udzieloną pośrednio przez Bourdieu i otwarcie przez Lareau, są nierówne zasoby kapitału ekonomiczno-kulturowego, których zobiektywizowaną formę stanowią najczęściej pieniądze i czas (jako konsekwencja posiadanego statusu zawodowego).

\section{Kapitał ekonomiczny obydwu grup rodziców}

Identyfikując zasoby kapitału ekonomicznego obydwu grup rodziców, można na pierwszy rzut oka pomyśleć, iż są one zbliżone. Zarówno w przypadku klasy szkoły X i Y organizowano wycieczki z dofinansowaniem; rodzice szkoły $X$ planowali zakup prezentów na koniec roku w hurtowni, co samo przez się wiązało się z niższym kosztem, natomiast rodzice szkoły $Y$ uzgodnili zakup podręczników na przyszły rok z jednego źródła - bo będzie taniej. Niemniej jednak, różnicę pomiędzy rodzicami szkoły X i Y w tej dziedzinie można było wychwycić w większości w ich niewerbalnych (a także w niektórych werbalnych) zachowaniach, które wymagają krótkiego zaprezentowania.

Przede wszystkim, w przypadku rodziców szkoły Y wyczuwało się, że kwestia finansowa stanowi pewnego rodzaju priorytet przy podejmowaniu decyzji związanych z edukacją. Pierwsze, potwierdzające tę tezę zachowanie, jakie zdołałam zauważyć, to pełna przerażenia twarz uczennicy spoglądającej na swoją mamę w momencie, kiedy przedstawiono koszt wyjazdu na zieloną szkołę bez dofinansowania - było to 520 złotych. Mina dziewczynki mówiła 
sama za siebie. Dopełnieniem tego stanu rzeczy była sytuacja, w której jedna z matek zaproponowała wspólny zakup podręczników, żeby obniżyć ich koszt, nie nabywając ich oddzielnie, jak to miało miejsce $w$ zeszłym roku. Sama treść wypowiedzi nie była tak wymowna, jak sposób jej przekazu - wypowiedziany stanowczym, mocnym tonem głosu, z nutą pretensjonalności, że to i tak późno, bo można było pomyśleć o tym sposobie zakupu wcześniej, gdyż - jak powiedziała matka: Pięćdziesiąt złotych to jest różnica!

$\mathrm{W}$ przypadku rodziców szkoły $\mathrm{X}$ wyczuwa się dbałość o zasoby finansowe w postaci tendencji do oszczędzania i braku rozrzutności, jednak pieniądze nie pełnią roli pierwszorzędnej, która ogranicza bądź narzuca im określony sposób działania $w$ polu edukacyjnym ich dzieci. To zupełnie inna perspektywa niż w przypadku rodziców szkoły Y, którą można zestawić w opozycję oszczędności z wyboru wobec oszczędności z przymusu. Tendencja ta przejawiła się chociażby w sposobie komunikowania się podczas planowania zakupu nagród w hurtowni. Kwestia finansowa nie wybrzmiała otwarcie ani razu. Żaden rodzic nie podkreślił na forum klasy, jak to uczyniła matka szkoły Y, że zaoszczędzona na hurtowym zakupie kwota ma znaczenie, choć prawdopodobnie ma. Jednakże, $\mathrm{w}$ przypadku rodziców szkoły $X$ nie urasta ona do rangi priorytetu, co stanowi o ich dystynkcji wobec rodziców szkoły Y.

\section{Rodzaje nawiązywanych relacji}

\section{Relacje rodziców z nauczycielem}

$\mathrm{W}$ dziedzinie relacji nawiązanych pomiędzy rodzicami a nauczycielem, szczególnie zaś w sposobie odnoszenia się do nauczyciela i prowadzenia rozmowy, istnieją pewne osobliwości typowe dla rodziców szkoły X i Y, zdeterminowane posiadanymi przez nich formami kapitału.

W przypadku rodziców uczniów ze szkoły muzycznej, relacje te mają charakter partnerski, a nawet, w niektórych sytuacjach, odniosłam wrażenie demonstrowania pewnego rodzaju wyższości nad nauczycielem, niejako obalając swoim zachowaniem jego autorytet. Ilustrację do tego spostrzeżenia stanowi sytuacja, zaistniała w trakcie jednej z lekcji w szkole X, podczas której ojciec uczennicy wszedł do klasy i niemalże bez słowa kazał się swojej córce spakować, oznajmiając tylko, że przyszedł ją zabrać. Postawa rodzica zaskakiwała stanowczością, ale w jeszcze większej mierze budziła zaskoczenie, ze względu na całkowity brak potrzeby wytłumaczenia nauczycielce swojego zachowania, podania konkretnego powodu przyjścia po córkę $\mathrm{w}$ połowie lekcji. Ojciec szkoły X nie czuł się w ogóle zobowiązany do złożenia jakiegokolwiek wyjaśnienia, a na bezpośrednie zapytanie zdezorientowanej nauczycielki: ale jak to, tak w trakcie lekcji?, nie udzielił żadnej odpowiedzi, ponad to, 
że córka nadrobi zaległości, na dowód czego poprosił o podyktowanie mu ćwiczeń, które dzieci miały w tym dniu zadane do domu. Ta pewność działania i swoista ignorancja nauczyciela, jako podmiotu posiadającego w klasie symboliczną władzę, pozwalają powtórzyć za Lareau, że rodzice o wyższych zasobach kapitałowych (niejednokrotnie o wyższym statusie zawodowym niż nauczycielski) czują się $\mathrm{w}$ polu edukacyjnym równorzędnymi podmiotami. Myślę, że w tym przypadku można mówić nawet o efekcie niespodzianki, bowiem Lareau przedstawiała relację rodzic - nauczyciel jako relację równości, nigdy natomiast nadrzędności ze strony rodzica, co w przedstawionym przypadku ewidentnie miało miejsce. Ponadto, specyfikę rodziców szkoły $\mathrm{X} w$ odnoszeniu się do nauczyciela ukazało ich zachowanie na wywiadówce. Charakteryzowało się ono bowiem w znacznym zakresie swobodą, a nawet żartobliwością, szczególnie w problematycznych momentach spotkania, kiedy nauczycielka skarżyła się na kłopoty w prowadzeniu lekcji z powodu braku przygotowania uczniów zarówno pod względem technicznym (brak przyborów), jak i merytorycznym (brak zadania domowego). Oto komentarz jednego rodzica w odniesieniu do wątku pierwszego, czyli braku przynoszenia przez uczniów wyposażenia szkolnego. $Z$ dwuznacznym uśmiechem i charakterystycznym tonem głosu, skwitował on falę negatywnych komunikatów wychowawczyni: Pani X [imię nauczycielki] wymyśla: jakieś kleje, nożyczki - za moich czasów tak nie byto, jakieś literki i tyle. Ten specyficzny rodzaj komentarza budzi ambiwalentne odczucia, ponieważ ton, w jakim został wypowiedziany brzmiał wobec adresata iście przyjacielsko, natomiast jego treść niejako podważała słuszność wypowiedzi nauczycielki. Na tym właśnie polega fenomen rodziców z klasy wyższej, którzy są "mistrzami” płynnego przechodzenia z postawy roszczenia bądź negacji, z jednej strony, do pewnego rodzaju spoufalenia $z$ drugiej - jakby grali z nauczycielem $w$ wyrafinowaną społeczną grę, polegającą na nieustannym lawirowaniu w myśl własnego illusio (interesu społecznego). Perspektywę żartobliwej, choć nieco bardziej bezpośredniej kontestacji przekazywanych przez nauczyciela komunikatów ukazuje również sytuacja, w której nauczycielka udzielała rodzicom instrukcji odnośnie ubioru scenicznego uczniów w czasie przedstawienia. Dialog brzmiał następująco:

- Wszystkie dzieci ubrane maja być na czarno - mówi wychowawczyni,

- Dlaczego na czarno? - pytają zaskoczeni rodzice,

- Bo czarny jest kolorem teatralnym.

Rodzice jednak nie ustępują:

- Jak ubrać dziecko na czarno? - pyta jedna z matek, dając do zrozumienia, że jest to dla niej niezrozumiały - w domyśle - niedorzeczny pomysł. Po chwili inny rodzic komentuje:

- I popetnimy zbiorowe samobójstwo. 
Ostatecznie, rodzice zgodzili się na czarny kolor. Niemniej jednak, najpierw wyrazili swoje zdanie na ten temat w sposób jasny, choć metaforyczny (metaforyka stanowi niewątpliwie ich cechę dystynktywną). Komentarz o zbiorowym samobójstwie, który był najdobitniejszą formą, w jakiej wyrazili swoją dezaprobatę wobec pomysłu nauczycielki, nie spotkał się z jej strony z żadną odpowiedzią, jakby wiedziała, że musi go „puścić mimo uszu”, gdyż ci rodzice $z a-$ wsze mają coś do powiedzenia. $Z$ kolei drugi zarzut nauczycielki pod adresem uczniów odnośnie braku zadań domowych, który notabene dokumentowała co do dni tygodnia i konkretnej liczby osób nieprzygotowanych, wywołał swoistą debatę wśród zgromadzonych opiekunów. Ostatecznie spotkał się z odzewem w postaci wyraźnej prośby części rodziców, żeby ich synowi/córce wstawić "patę" w razie braku zadania domowego, ponieważ trzeba od dzieci wymagać i już. Widać zatem tradycyjny rodzicielski dyskurs wymagania względem własnych dzieci z jednej strony, przy jednoczesnej stanowczości i odrobinie pretensjonalności względem nauczyciela z drugiej, spowodowanej faktem, że nie wymaga od dzieci tak jak powinien, a wymagać trzeba: $i$ juz.

Odnośnie rodziców szkoły $Y$, ich relacje $\mathrm{z}$ nauczycielem prezentują się $\mathrm{w}$ innym świetle. Co prawda, nie mają one jednolitego charakteru, ponieważ zachowania rodziców względem nauczyciela się różniły, to jednak z całą pewnością nie cechowała ich nadrzędność. Autorytet nauczyciela w szkole Y był przez rodziców szanowany i nie ma co do tego wątpliwości. I chociaż zdarzały się pod jego adresem żarty, to jednak nie były one wypowiadane na forum, lecz wyłącznie między rodzicami (a miałam sposobność usłyszeć jeden z nich, siedząc w ostatniej ławce, gdzie dystans dzielący rodziców i nauczyciela sprzyjał tego typu wypowiedziom). Jedna z wypowiedzi miała miejsce w kontekście omawianych przez wychowawczynię warunków panujących w ośrodku, do którego mieli się udać uczniowie szkoły $\mathrm{Y}$ w ramach wycieczki klasowej. Żartobliwa i jednocześnie konspiracyjna riposta rodzica szkoły $Y$ na słowa wychowawczyni o niedziałaniu telefonów komórkowych na terenie ośrodka brzmiała: A światło jest? Tego rodzaju wypowiedzi rodziców szkoły Y, wywołujące śmiech u pozostałych, pokazują, że mimo własnego zdania w postaci niejednokrotnie krytycznych uwag pod adresem nauczyciela bądź sposobu funkcjonowania szkoły, brakuje im tej „odwagi”, czy też pewności, jaką zapewnia prawomocny kapitał kulturowy, by wyrazić je w sposób jawny. Oznacza to, że rodzice ci, podobnie jak ich dzieci, nie czują się w szkole jak „u siebie”, dlatego nie wyrażają swojego stanowiska w pełni, co w konsekwencji decyduje o relatywnym braku roszczeniowości z ich strony. Ogólnie rzecz biorąc, ta grupa rodziców była stosunkowo skromna $\mathrm{w}$ relacjach $\mathrm{z}$ nauczycielem, nieskora do przeprowadzania z nim długich rozmów, wykazująca mimo wszystko znaczny szacunek wobec jego autorytetu. Trudno również zauważyć w relacjach rodziców szkoły Y z nauczycielem jakiekolwiek prze- 
jawy tej wyrafinowanej gry, jaką prowadzą rodzice szkoły $X$, ze względu na przypuszczalny (w przypadku większości z nich) brak znajomości jej zasad, o których decyduje habitus i zasoby kapitałowe.

Zatem, ugodowość, rzadkie i skrzętnie ukrywane przejawy krytycyzmu, podporządkowanie oraz skromność $\mathrm{w}$ relacjach stanowią wykładnię stosunku rodziców szkoły $\mathrm{Y}$ wobec nauczyciela. W przypadku rodziców szkoły X, ich odpowiednikami są stanowczość i roszczeniowość, zawoalowana w swobodę i relacje przyjacielskie.

\section{Relacje rodziców $z$ dyrekcja}

$\mathrm{Z}$ wypowiedzi jednego $\mathrm{z}$ rodziców szkoły $\mathrm{X}$ wynika, że relacje $\mathrm{z}$ dyrekcją układają się pomyślnie i władze szkoły charakteryzują się dużą otwartością na rodzicielskie postulaty. Dowodzi tego chociażby fakt, że w przypadku jego starszej córki, która również uczęszczała do tej samej szkoły muzycznej, w wyniku niezadowolenia rodziców z powodu słabych efektów pracy dydaktycznej nauczyciela, klasa otrzymała innego wychowawcę. Widać zatem skuteczność interwencji rodzicielskiej, wzmacniającą w rodzicach poczucie, że "dużo mogą". Fakt ten znajduje odzwierciedlenie w dalszej części opowieści rodzica, który nawiązując do klasy szkoły X i jego młodszej córki, nie ukrywał, że był kilkakrotnie na rozmowie z dyrekcją, ponieważ nie zgadzał się (i jak twierdzi - nie była to wyłącznie jego opinia) z metodami stosowanymi przez nauczycielkę $X$. W rozmowie ze mną wyraził się jasno, że dzieci byty uczone wiedzy oderwanej od rzeczywistości - tzw. "sztucznie” trudnych rzeczy, nie znając jednocześnie podstaw. Ponadto, wyraźnie obwiniał on nauczyciela za brak wykonywania zadania domowego przez uczniów, ponieważ: nauczycielka zadawała zbyt dużo i zbyt trudne rzeczy do domu lub niewłaściwie je tłumaczyła. Widać zatem całą listę zarzutów pod adresem wychowawczyni, na której jednak nie poprzestał. Ojciec uczennicy X dodał również, kwestionując tym samym decyzję nauczycielki, że wysłała jego córkę do poradni psychologiczno-pedagogicznej, tymczasem w trakcie dni wolnych jego córka nadrobiła wszystkie zaległości. Rodzic pochwalił się także, że nauczył ją nawet mnożyć w zakresie stu, co w przypadku tej sześcioletniej dziewczynki, z którą zetknęłam się w czasie odbywanych praktyk, zabrzmiało dość fantazyjnie. Niemniej jednak, rezultat powziętych przez niego działań był taki, iż jak twierdził: $z a-$ uważyt, że nauczycielka teraz zmieniła taktykę. Konfrontując jego wypowiedź z relacją wychowawczyni, otrzymałam dość sprzeczne informacje, gdyż wyraziła się ona o rodzicu jednoznacznie twierdząc, że: tylko on miał z tym problem, więc się skończyło. Niemniej jednak, roszczeniowa postawa ojca szkoły $\mathrm{X}$ jest faktem, bez względu na to, czy nauczycielka zmieniła swoją metodyczną strategię czy też nie, tak samo jak faktem jest, że klasie jego starszej córki, $\mathrm{w}$ wyniku interwencji rodziców, przydzielono innego nauczyciela. 
Natomiast, w przypadku rodziców szkoły Y żadna wypowiedź o podobnym charakterze nie miała miejsca. Wręcz przeciwnie, w jednej z przeprowadzonych rozmów odnosiło się wrażenie, że matka ucznia szkoły Y deklamuje swoisty panegiryk na cześć dyrekcji, wyrażając się o niej w superlatywach, typu: Pani dyrektor jest bardzo dobra, działa prężnie, to z jej inicjatywy dzieci maja zeszyty czytelnicze (...) Organizuje dużo zajęć dodatkowych, gdy dziewczynka skręciła ręke na terenie szkoty, od razu sprawnie zareagowała (...) czy też w innym miejscu: Nawet najlepszy nauczyciel nie może dużo zdziałać, gdy nie ma pomocy $i$ wsparcia dyrekcji, ale tutaj dyrekcja działa bardzo dobrze. Ów rodzicielski punkt widzenia przedstawia się niezwykle ciekawie szczególnie w zestawieniu ze sposobem, w jaki sama nauczycielka wyrażała się o pani dyrektor. Matka ucznia szkoły $\mathrm{Y}$ podobnie wypowiadała się również o nauczycielce swojego syna, która jej zdaniem: radziła sobie bardzo dobrze. W zasadzie, jedyny mankament szkoły $Y$, jaki wymieniła, miał charakter infrastrukturalny, gdyż matka Y powiedziała, że świetlica mogłaby być większa, gdyż okazywała się dla uczniów niewystarczająca. Ów charakterystyczny brak krytycyzmu można wytłumaczyć, innym niż w przypadku rodziców X, habitusem klasowym, czyli sposobem postrzegania i oceniania rzeczywistości społecznej. Abstrahując od wyraźnie zauważalnej dominacji dyrekcji w szkole Y oraz od uwarunkowań instytucjonalnych szkoły, sprzyjających silnemu zaangażowaniu jej władz $\mathrm{w}$ doskonalenie programu zajęć, podlegającego permanentnej ocenie, które same przez się ukazywały panią dyrektor w pozytywnym świetle osoby prężnie działającej, równie istotną przyczyną takiego nastawienia rodziców szkoły Y jest, mimo wszystko, określony sposób myślenia, który wyklucza zachowania roszczeniowe. Po raz kolejny rodzice ci, nie będąc "u siebie", gdyż podobnie jak w przypadku ich dzieci, szkoła jest dla nich środowiskiem obcym, traktują to co od niej otrzymują (edukację - jakakolwiek by nie była) bardziej w kategoriach daru (wobec którego „nie wypada” rościć sobie żądań) niż tego, co im się de facto "należy”.

\section{Zakończenie}

Przedstawione powyżej badania i wnioski nad teorią reprodukcji społeczno-kulturowej nie pozostawiają wątpliwości co do zastosowanej w tytule artykułu dychotomii: "roszczeniowość vs ugodowość” rodzicielskich postaw w szkole. Widoczna jest ona bowiem zarówno na płaszczyźnie nawiązywanych relacji z poszczególnymi reprezentantami instytucji szkoły, jak i w ramach zaangażowania oraz uczestniczenia w życiu szkoły (przede wszystkim w edukacji swoich dzieci), a także na poziomie edukacyjnych aspiracji posiadanych przez obie grupy rodziców, której przyczyny upatrywać należy 
w niejednakowych zasobach kapitału ekonomiczno-kulturowego. Innymi słowy, po jednej stronie rodzicielskiej barykady mamy rodziców dowcipnych, pewnych siebie, uważających się $\mathrm{w}$ stosunku do nauczyciela za równorzędnych, a czasem nawet "lepszych” (lepiej wykształconych) partnerów, którzy prowadzą swoistą grę o interes swoich dzieci; rodzice ci wykazują postawy roszczeniowe i gotowi są pójść na skargę do dyrekcji, jeśli nie zgadzają się ze sposobem prowadzenia zajęć przez nauczyciela, mimo że ten - jak sam się wyraził - "trzyma ich 'krótko'”. Wskutek takiej postawy, relacja rodziców z dyrekcją jest relacją aktywną, gdyż spotykają się oni z reakcją zwrotną, respektującą ich postulaty i podejmującą konkretne działania w kierunku ich realizacji. $\mathrm{W}$ związku z tym rodzice angażują się $\mathrm{w}$ działania na polu edukacyjnym, dokładając wszelkich starań, by ich dzieci były prowadzone w jak najlepszy (ich zdaniem) sposób. Po drugiej zaś stronie pojawiają się rodzice skromni, nieskorzy do debat i nade wszystko ugodowi, prowadzący grę na zupełnie innych zasadach; polega ona na swoistym kredycie zaufania wobec szkoły, i związanym z nim afirmowaniu jej postanowień, oraz pewnego rodzaju przyjęciem za pewnik faktu, że skoro dziecko jest w szkole, szkoła go z pewnością odpowiednio przygotuje; nie ma zatem $\mathrm{z}$ ich strony potrzeby ani woli ingerencji w edukacje dzieci. Taka postawa wynika niejednokrotnie z niższych kwalifikacji zawodowych (tożsamych z kapitałem kulturowym) tej grupy rodziców, którzy niejako „zdają się" na szkołę i wiedzę nauczyciela. Stąd również relacja dyrekcja - nauczyciel jest w ich przypadku relacją całkowitego podporządkowania. Stosunki z nauczycielem charakteryzują się życzliwością i brakiem roszczeniowości. Żaden rodzic szkoły Y nie chodzi do dyrektora, by wyrazić swoje niezadowolenie $\mathrm{z}$ powodu pracy nauczyciela. $\mathrm{W}$ rozmowie $\mathrm{z}$ rodzicami szkoły $\mathrm{Y}$ odnosiło się wręcz wrażenie, że postawa taka nie przyszłaby im nawet na myśl, gdyż nie jest zgodna $\mathrm{z}$ ich sposobem myślenia o właściwym zachowaniu w szkole (habitusem). Brak jakiejkolwiek ingerencji rodziców o niższym statusie społecznym w polu osiągnięć edukacyjnych ich dzieci pozostaje kolejnym faktem, który sprawia, że świat szkolny ich dzieci kontrastuje ze światem szkolnym dzieci uprzywilejowanych statusem pochodzenia do tego stopnia, iż można je postrzegać jako dwie odrębne rzeczywistości, w których rodzicielskie postawy różnią się za sprawą posiadanych zasobów kapitałowych oraz - ściśle z nimi związanych - habitusów klasowych.

\section{BIBLIOGRAFIA}

Babbie E., Badania społeczne w praktyce, przekł. A. Betlejewska, Wydawnictwo Naukowe PWN, Warszawa 2005.

Bourdieu P., Dystynkcja. Społeczna krytyka władzy sądzenia, przekł. P. Biłos, Wydawnictwo Naukowe Scholar, Warszawa 2005. 
Bourdieu P., Passeron J.-C., Reprodukcja. Elementy teorii systemu nauczania, przekł. E. Zamojska, Wydawnictwo Naukowe UAM, Poznań 1992.

Bourdieu P., Wacquant L.J.D., Zaproszenie do socjologii refleksyjnej, przekł. A. Sawisz, Oficyna Naukowa, Warszawa 2001.

Clark J., Social justice, education and schooling: some philosophical issues, British Journal Studies, 2006, 54(3).

Cylkowska-Nowak M., Refleksja teoretyczna nad problemem równości - analiza wybranych koncepcji, [w:] Idee-Diagnozy-Nadzieje. Szkoła polska a idee równości, red. A. Męczkowska-Christians, P. Mikiewicz, Wydawnictwo Naukowe DSW, Wrocław 2009.

Długosz P., Społeczne skutki zmian systemu edukacji, [w:] Zawirowania systemu edukacyjnego, red. M. Zahorska, Wydawnictwa UW, Warszawa 2012.

Gdula M., Sadura P., Style życia i porządek klasowy w Polsce, Wydawnictwo Naukowe Scholar, Warszawa 2012.

Giddens A., Constitution of Society, University of California Press, Berkeley 1984.

Giddens A., Socjologia, przekł. A. Kubikowska, Wydawnictwo Naukowe PWN, Warszawa 2004.

Hammersley M., Atkinson P., Metody badań terenowych, Zysk i S-ka Wydawnictwo, Poznań 2000.

Klebaniuk J. (red.), Fenomen nierówności społecznych, Wydawnictwo Eneteia, Warszawa 2007.

Kwieciński Z., Wolność czy równość w edukacji? [w:] Idee-Diagnozy-Nadzieje. Szkoła polska a idee równości, red. A. Męczkowska-Christians, P. Mikiewicz, Wydawnictwo Naukowe DSW, Wrocław 2009.

Merton R.K., Teoria Socjologiczna i Struktura Społeczna, PWN, Warszawa 1982.

Męczkowska-Christians A., Mikiewicz P. (red.), Idee-Diagnozy-Nadzieje. Szkoła polska a idee równości, Wydawnictwo Naukowe DSW, Wrocław 2009.

Mikiewicz P., Społeczne światy szkót średnich. Od trajektorii marginesu do trajektorii elit, przekł. E. Morawska, J. Wertenstein-Żuławski, Wydawnictwo Naukowe DSW, Wrocław 2005.

Mikiewicz P., Selekcja i segmentacja społeczna jako immanentna funkcja systemu edukacji, [w:] Fenomen nierówności społecznych, red. J. Klebaniuk, Wydawnictwo Eneteia, Warszawa 2007.

Roberts H., Listening to Children: and Hearing Them, [w:] Research with Children, red. P. Christensen, A. James, Routledge, New York 2000.

Sorokin P., Ruchliwość społeczna, przekł. J. Słomczyńska, Wydawnictwo PAN, Warszawa 1968.

Szkudlarek T., Edukacja i konstruowanie społecznych nierówności, [w:] Fenomen nierówności społecznych, red. J. Klebaniuk, Wydawnictwo Eneteia, Warszawa 2007.

Szlendak T., Socjologia rodziny. Ewolucja, historia, zróżnicowanie, przekł. B. Bińko, Wydawnictwo Naukowe PWN, Warszawa 2010. 